\title{
VOHTENKELLARINSUO, A BOG IN PAIMIO, SW FINLAND WITH A CULTURAL ORIGIN
}

\author{
IRMELI VUORELA
}

\begin{abstract}
VUORELA, IRMELI, 1983: Vohtenkellarinsuo, a bog in Paimio, SW Finland with a cultural origin. Bull. Geol. Soc. Finland 55, 1, 57-66. The present investigation describes the development of the bog Vohtenkellarinsuo and the history of the local settlement of the Paimio river valley.

Both the stratigraphy and the pollen data of the peat profile reflect continuous human interference from the period of Kiukainen Culture (4000-3300 B. P.) onwards. The destruction of the local deciduous forest by fire during the Roman Iron Age was followed by phases of cultivation and grazing that caused changes in the water balance of the soil in the area. This led to the development of Sphagnum peat and thus to the birth of the bog.
\end{abstract}

Key words: Pollen, stratigraphy, human interference, settlement history, Paimio.

Irmeli Vuorela: Department of Geology, Division of Geology and Palaentology, University of Helsinki, P. O. Box 115, SF-00171 Helsinki 17, Finland.

\section{Introduction}

In 1980 the author was asked by the Archaeological Institute of the University of Turku to carry out pollen analytical investigations in the eastern Paimio river valley in the commune of Paimio, SW Finland* in order to throw light on the history of local settlement. The soil and topography of the area are such that only a few sites are appropriate for pollen analysis. The scarcity of suitable bogs or lakes close to the valley restricted our choise to the bog Vohtenkellarinsuo. The pollen stratigraphy of the same site has been described earlier by Glückert (1976, 1977)

\footnotetext{
* (Basic Map sheet No, 2021 03)
}

though the amount of pollen counted for his purposes was insufficient for interpretation of local human influence on the vegetation. Since the pollen stratigraphical horizons dated by $\mathrm{C}^{14}$ for Glückert easily correlate with the present profile, they did not need to be checked in the present work. The crucial date for the present studies, that of the ash layer at a level of c. $50 \mathrm{~cm}(1640 \pm 130$ B. P., Hel-123), provides the base for agricultural activity in the environment. Roughly the same age (1550 \pm 160 B. P., Hel-1431) was obtained for the first Cerealia pollen in the sediments of Kuoppajärvi, a lake in the neighbouring commune of Piikkio, by Salonen et al. (1981: 10). Their paper also gives a more detailed diagram for the fluctuation of 
the agricultural indication during these 1.5 decades.

As Vohtenkellarinsuo is located in a forested area $1 \mathrm{~km}$ from the biggest fields in the principal river valley, the present pollen data mainly reflect human activity in the area and its influence on the origin and development of the bog itself and its surroundings.

\section{Geological and historical background}

The dominant quaternary deposits in the area are the thick layers of marine clay filling not only the Paimio river valley but also the small areas between the "archipelago" of bedrock outcrops in the coastal area. In addition, "islets» of till emerge from the clay together with deposits of more washed material, sand and gravel along the southern and south-western sides of the islets.

The topography of the eastern Paimio river valley reaches $80 \mathrm{~m}$ a.s.l. (Fig. 1). Geologically this area is part of an area of moraine hummocks covering close on $2 \mathrm{~km}^{2}$. The recent settlement of Paimio is concentrated largely in this area, south of which the depressions in the bedrock are filled with till. The southern part of the area is conspicuous for its thick sand deposits. The topography suggests that the islets described emerged from the sea in early postglacial time. The $20 \mathrm{~m}$ isobase indicates the location of the shore line c. 4000 years ago during the period of Kiukainen Culture (4000-3300 B. P., Siiriäinen 1974) as demonstrated by several stray finds in the surroundings of the sampling site (National Board of Antiquities, Erkola 1973). The high level of the ground water gave rise to waterlogged sites. They mark the start of a small estuary of the Paimio River (Fig. 1), which passes the younger bog Vohtenkellarinsuo and flows downvalley between the high rocks west of the bog. The sandy estuary valley may well have offered a sheltered dwelling site for people of the Bronze Age as docu- mented by two burial cairns 1 and $2 \mathrm{~km}$ southwest of Vohtenkellarinsuo (National Board of Antiquities, Helsinki; Fig 1). The Iron Age settlement, which occupied several sites immediately north of Paimio, is represented in the area in question by only one site with finds in the main river valley, $2 \mathrm{~km}$ northwest of Vohtenkellarinsuo.

As shown on the diagram published by Glückert, the local forest vegetation in the Bronze Age was dominated by deciduous trees and the soil was tillable. The location of the earliest fields by the estuary is shown in a map made in the 1870 s (Fig. 2). According to the village register there had been two households in Kerkkola already some 300 years earlier. What is more, the extensive wetlands north to northwest of and including Vohtenkellarinsuo were recorded in 1909 as suitable for sporadic cultivation (lined on map Fig. 3). How long such activities had been going on in the area may be established by the present investigation. By the time the later map was made the whole main river valley was cultivated; in the 1870 map (Fig. 2) the area had been recorded as a »sea meadow", and it is possible that it was used as grazing land with no more than a few tiny field plots (cf. Salo 1970: 182).

During the present field work, old ditches $80 \mathrm{~cm}$ wide, $20 \mathrm{~cm}$ deep and filled with $20-30 \mathrm{~cm}$ of sand, were found at the southern end of Vohtenkellarinsuo. Well humified Carex peat but no Sphagnum peat was overlain by sand deposits in the ditches. The Sphagnum-dominated peat between the ditches supports a dense Betula forest. The old ditches were crossed by recent ones c. $1 \mathrm{~m}$ deep.

During the last few decades human activity has altered the structure and the water balance around and at Vohtenkellarinsuo. The Turku-Helsinki highway crosses the bog, the wet areas have been drained and peat has 


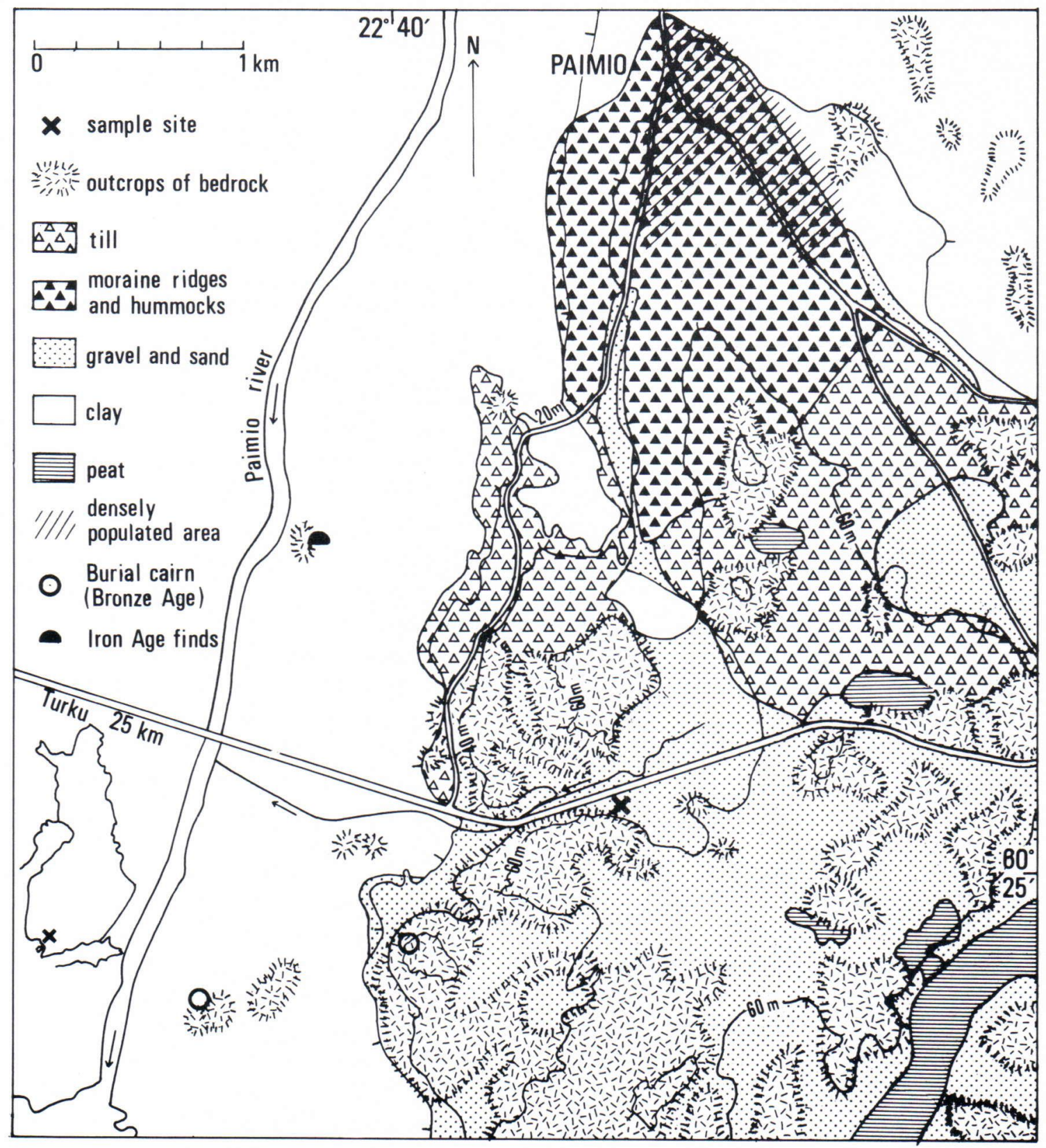

Fig. 1. A map showing the geological, topographical and archaeological components of the surroundings of the sample site. The quaternary deposits refer to those at a depth of $1 \mathrm{~m}$.

been taken for industry. A high-voltage power line was recently constructed across the area, destroying what remained of the natural forest vegetation.

\section{Material and methods}

The site is located in southern Vohtenkellarinsuo, south of the present highway (Fig. 


\section{Kerkkola 1879}

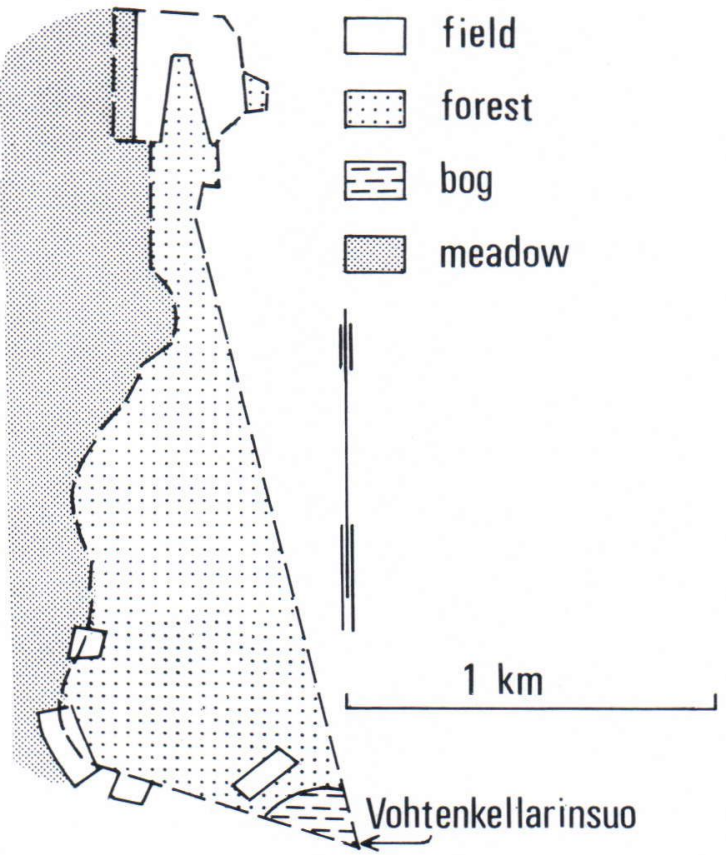

Fig. 2. The map made in the 1870 s showing the location of the early agricultural fields in the estuary valley, in the village of Kerkkola, west of Vohtenkellarinsuo.

1). The samples were collected in September 1980 with three metal troughs measuring $10 \times 10 \times 50 \mathrm{~cm}$ each from a vertical sediment face.

A hiatus has already been recorded at the sand/peat contact (Glückert 1976). Besides the basal sand, a layer of sand $2-3 \mathrm{~cm}$ thick was found at the $117-120 \mathrm{~cm}$ level. The layer was thought to mark the fluctuations of former small streams in the area. The stratigraphy of the peat deposits at the sample site was as follows:

0-35 cm mainly Sphagnum peat. Leaves of Eriophorum and Carex in minor amounts.

35-145 cm mainly well humified Carex peat with a high abundance of wood remains (Alnus and Betula) especially at the $40-55 \mathrm{~cm}$ and 90-95 cm levels. Sphagnum remains at the 35-50 cm level in minor amounts. Equisetum at the bottom of the sediment core.

Ash and carbonized wood found at the $5-10 \mathrm{~cm}$ and $45-50 \mathrm{~cm}$ levels appeared to be widely distributed in the area, especially at the $45-50 \mathrm{~cm}$ level.

The recent vegetation of the southern part of Vohtenkellarinsuo is dominated by dwarf shrubs: Calluna vulgaris, Ledum palustre and Vaccinium uliginosum. The tree vegetation has been badly destroyed by human activity, and Pinus and young Betula occur in no more than minor amounts. The recent mosses at the site are: Polysetum (Dicranum) undulatum, P. scoparium, Sphagnum fuscum, Polytrichum juniperinum and Pleurozium schreberi.

The macrofossils were studied from the $0-50 \mathrm{~cm}$ level on five $10-\mathrm{cm}$ samples. Excluding the sample at the $40-50 \mathrm{~cm}$ level, the Sphagnum peat samples contained no or only sporadic seeds of the local natural vegetation.

For the pollen analysis the samples were taken at 5 -cm intervals and prepared by the $\mathrm{KOH}$ and acetolysis methods (Faegri \& Iversen 1975). A total of 1000 arboreal pollen grains (AP) was counted at each depth. The results are expressed as percentages of AP for all the pollen groups: trees, shrubs, natural open land herbs, apophytes and antropochores, and cryptogams. Because of the heterogeneity of the peat caused by the wood remains, the pollen concentration values were not reliable enough to be calculated.

The dates in the diagram (Fig. 4) are mainly based on those determined by the Radiocarbon Dating Laboratory, Helsinki, for Glückert (1976). As the cores for these two investigations were sampled from the same site and the levels dated correlate well with the pollen chronology, the historical correlation can be carried out with sufficient accuracy. The datings are as follows: 


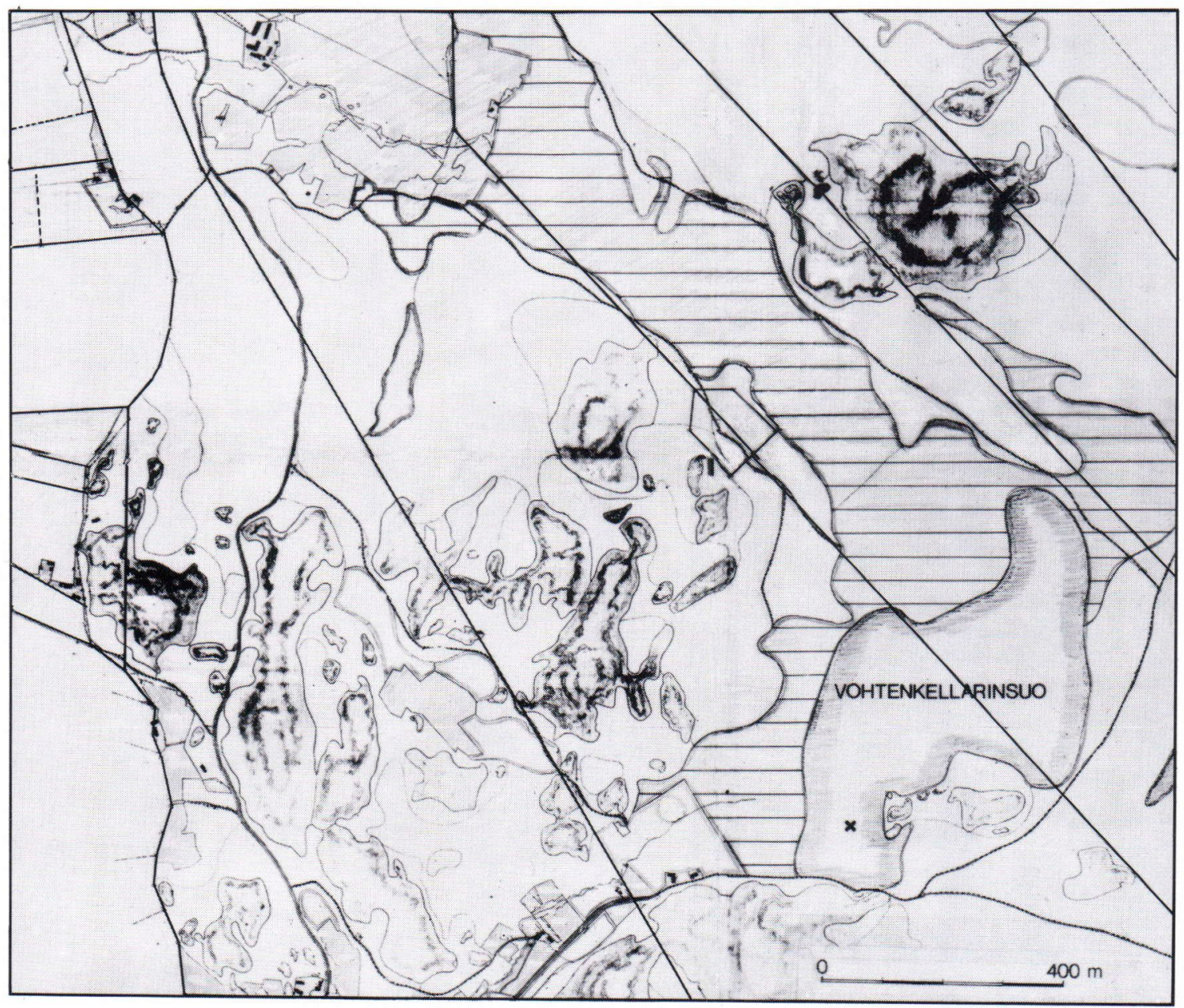

Fig. 3. A slightly modified map of that made in 1909 showing the position of the bog Vohtenkellarinsuo the sample site (x) and the areas recorded as tillable (lined). Published with permission of the General Survey Office.

in Glückert 1976

$1640 \pm 130$ B.P. $\quad$ AD 310
$2550 \pm 150$ B.P. 600 BC
$3790 \pm 170$ B.P. 1840 BC
$5220 \pm 190$ B.P. 3270 BC

object dated

layer of ash at $60 \mathrm{~cm}$

rise in Picea curve

wood in peat at $120 \mathrm{~cm}$

wood below Carex peat used here as
AD 300
$600 \mathrm{BC}$
$1800 \mathrm{BC}$
$3300 \mathrm{BC}$

An additional $\mathrm{C}^{14}$ date determined for the 23-27 cm level of the end of the post-Iron Age grazing phase indicated by the Gramineae and Ericaceae maxima (Fig. 5) gave $710 \pm 100$ B.P. $($ Hel-1745) $=$ AD 1240 .

\section{The early vegetational history of the site}

According to the datings, the core covers the Sub-Atlantic and the Sub-Boreal Chronozones down to the Atlantic Chronozone 

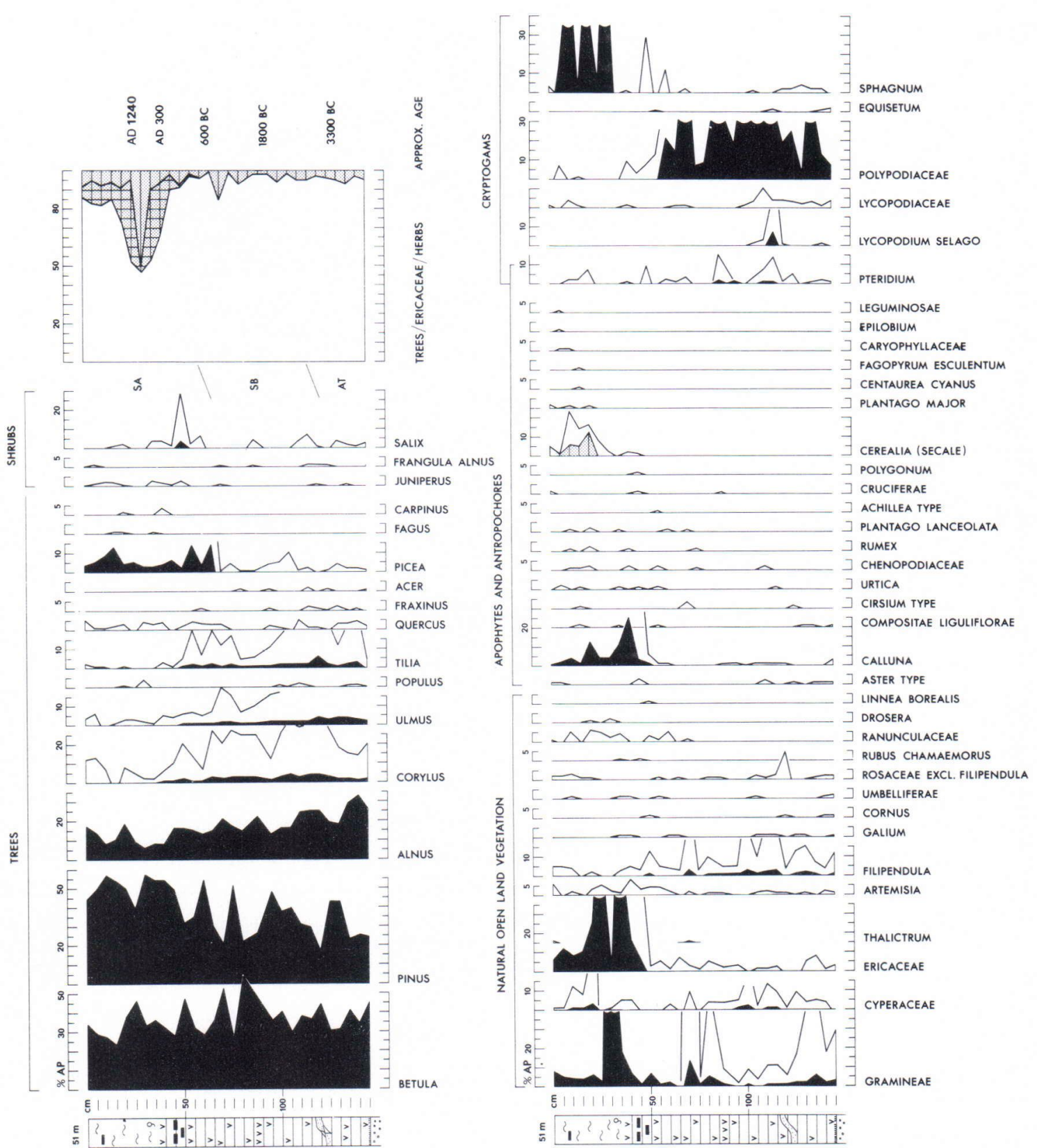

Fig. 4. The relative pollen frequencies of the profile of Vohtenkellarinsuo. The dating of the diagram is mainly after Glückert (1976).

(Mangerud et al. 1974). This is also shown by the pollen stratigraphy with high relative frequencies for the QM species (Corylus, Fraxinus, Tilia, Quercus and Ulmus) in the lower part of the diagram (Fig. 4). The high ground-water level and the moist soil conditions at that time are indicated by the almost constant Salix curve, and by the dominant 
herb pollen of Filipendula and spores of Polypodiaceae. The occurrence and the indication of small local streams have been discussed above. The AP/NAP ratio suggests that the vegetation of that time was of closed forest.

At the 90-95 cm level some features in the AP ratios indicate a disturbance in the forest composition. The relative frequencies of all the broadleaved trees decrease simultaneously, while those of the pioneer species, Betula, Alnus and Corylus, increase. In the peat stratigraphy this phase coincides with the horizon especially rich in uncarbonized wood remains. No ash layer or other clear evidence of human activity can be detected. The brief depression in the Polypodiaceae together with the increase in Pteridium may reflect a change in the field vegetation (Vuorela 1980). These features are not very marked and must be fairly local as shown by the special pollen dispersion and filtration in a dense deciduous forest with a Salix border (Tauber 1967, Vuorela 1973). The phase has an approximate age of $1800 \mathrm{BC}$, i.e. the period of Kiukainen Culture. At that time the estuary valley had already emerged from the sea and formed a convenient dwelling area.

The deciduous AP species described above recovered before the next big vegetational change caused by the invasion of Picea. This event, which took place at c. $600 \mathrm{BC}$, is recorded at the $70 \mathrm{~cm}$ level in the diagram. The simultaneous decrease in the pollen frequencies of broadleaved forests can be attributed to the climatic deterioration which took place in the Sub-Boreal / Sub-Atlantic (or Bronze Age/ Iron Age) transition. The possibility of additional human impact cannot be discounted, however, because the phase is preceded by an increase in NAP pollen, both natural (Gramineae) and hemerophilous (Chenopodiaceae, Rumex and Plantago lanceolata; Linkola 1916) and another clear depression in the Polypodiaceae curve. Referring to the distance and the topography between the sample site and the shore line at that time there is no reason to interpret the above apophytes as part of the seashore vegetation (cf. Fries 1951, Iversen 1964). It is more probable that they indicate local Bronze Age activity in the estuary valley. After the latter phase a continuous indication of human activity is recorded in the pollen spectra, starting with a sharp decrease in Picea pollen and a great abundance of Salix pollen at the $50 \mathrm{~cm}$ level (Fig. 5) together with marked fluctuations in the relative AP frequencies. The diagram does not, however, reveal any traces of agricultural activity.

\section{The development of the bog Vohtenkellarinsuo}

The most drastic event in the history of Vohtenkellarinsuo seems to have been the cutting and burning of the forest at c. AD 300 , i.e. The Roman Iron Age. This is indicated in a wide area around the sample site by a layer of ash and carbonized wood remains at a mean depth of $50 \mathrm{~cm}$. In the sediment core investigated, this layer was found at the 45-50 cm level (Figs 4,5). The only pollen indicators of local slash-and-burn cultivation are sporadic pollen grains of Cerealia, Polygonum and Cruciferae. The occurrence of Cerealia marks the start of cultivation in this part of the Paimio area, a finding that is consistent with that of Salonen et al. (1981) from the western Paimio river valley. The clear decrease in the spores of Polypodiaceae in a preceding phase $(55 \mathrm{~cm})$ together with the carbonized fragments of Calluna at the $40-50 \mathrm{~cm}$ level confirm that, as suggested above, the vegetational composition had changed even before the burning phase. It also confirms that the course of the soil development of the area had been 
Vohtenkellarinsuo, Paimio

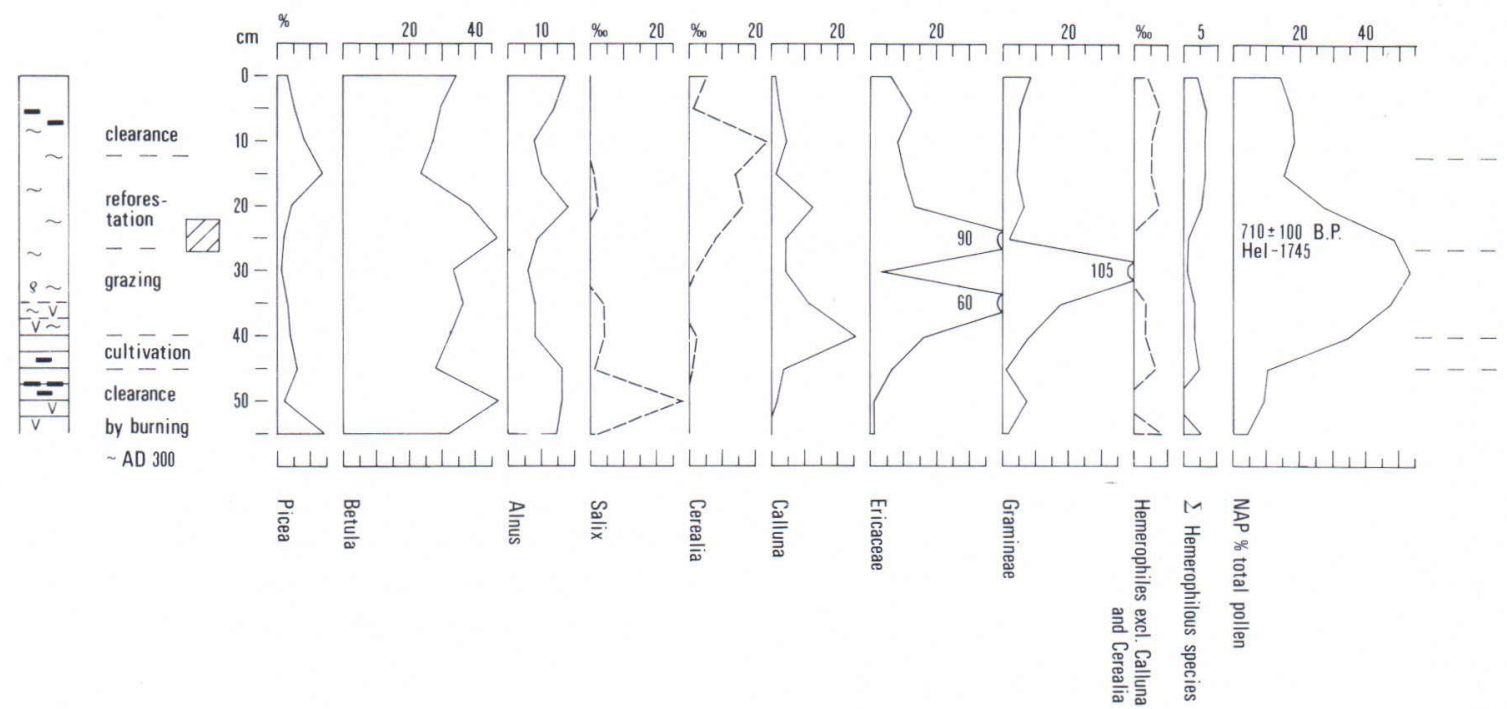

Fig. 5. Relative pollen diagram of selected species and pollen types showing local indications of human activity.

towards more acidic conditions (cf. Iversen 1969).

The pollen and spores of the natural herb and cryptogam vegetation at the burning level reflect the start of considerable local changes that finally led to the development of Sphagnum peat and to the bog Vohtenkellarinsuo.

Microscopic analysis of the vegetational fragments from the peat layer at the $0-50 \mathrm{~cm}$ level and the macrofossil remains (Carex sp. seeds) found in the peat samples at the 40-50 $\mathrm{cm}$ level show that the site remained as Carex peat immediately after the burning phase of $\mathrm{AD} 300$. The slow invasion of the site by Sphagnum species thereafter is natural as the high ash content must have resulted in $\mathrm{pH}$ values too high for the Sphagnum species to tolerate (cf. Dimbleby 1957: 18). It was only after a period during which the nutritients were washed off that the $\mathrm{pH}$ values were low enough for Sphagnum. This first period after the burning phase is characterized by Cerealia pollen and a marked increase in Calluna pollen (Fig. 5), a species which is known to reflect and favour higher acidity (Havinga 1963). The later brief Gramineae phase at the $27-35 \mathrm{~cm}$ level that was both preceded and followed by high Ericales pollen frequencies could correspond to a local grazing period (Behre 1981), where the high NAP ratio (53\%) also suggests open vegetation. The end of this phase, which is also indicated by the abnormally low Picea pollen frequencies typical of grazing land (Heikinheimo 1915), was dated by $\mathrm{C}^{14}$ to $710 \pm 100$ B.P. (Hel-1745). It was only during this period that the Sphagnum peat became predominant, which is how it continues up to the surface layers of the core. It is obvious that the destruction of the forest in c. AD 300 by fire and the following grazing period influenced the water balance and the soil chemistry at the site, thereby making it possible for bog mosses to grow later (cf. Iversen 1973).

The historical data quoted above show that the area around and north of Vohtenkellarin- 
suo has occasionally been cultivated. The pollen of the apophytes and the anthropochores, such as Cerealia, Centaurea cyanus, Fagopyrum esculentum, Caryophyllaceae and Plantago major at the $15-20 \mathrm{~cm}$ level, clearly reflect settlement and cultivation in the estuary valley west of Vohtenkellarinsuo and in the area north of it. This activity did not extend to the sample site itself. On the contrary, the phase is characterized by features indicating local reforestation as shown by the decrease in the relative NAP frequencies together with a successional increase in Betula and Alnus and especially in Picea.

A more recent burning phase indicated by Epilobium pollen, ash and carbonized wood remains was found close to the surface combined with another decrease in Picea starting at the $15 \mathrm{~cm}$ level. This phase with a Cerealia pollen maximum at the $10 \mathrm{~cm}$ level could be associated with the digging of the ditches found south of the sampling site.

\section{Summary}

Pollen analytical investigations were carried out at Vohtenkellarinsuo, a bog in Paimio, SW Finland, that has no more than $40 \mathrm{~cm}$ of Sphagnum peat.

Only an indistinct reflection of human activity was recorded for the period of Kiu-

\section{References}

Behre, K.-E., 1981. The interpretation of anthropogenic indicators in pollen diagrams. Pollen et Spores 23, 225-245.

Dimbleby, G. W., 1957. Pollen analysis of terrestrial soils. The New Phytologist 56, 12-28.

Erkola, T., 1973. Paimion esihistoria. In: Erkola, T., Hertzen, E. and Innamaa, K. (eds.): Paimion historia. Hämeenlinna. 958 pp.

Faegri, K. \& Iversen, J., 1975. Textbook of pollen kainen Culture (4000-3300 B.P.). Later the Bronze Age settlement caused more clear fluctuations in the pollen spectra of the wellhumified Carex-forest peat although the earliest indications of agriculture did not appear until the Iron Age.

The development of the bog was investigated in the southern part of the bog only. It seems apparent, however, that the start of the growth of Sphagnum peat was closely associated with local human interference. Forest fires in the area, a slash-and-burn cultivation phase around AD 300 and the following grazing period seem to have changed the former water balance, the basic status and the nutrient economy of the site. As no climatic change took place at that time, the development of the bog has been attributed to human activities.

The local pollen assemblage zones in the Sphagnum peat layer reflect the post-Iron Age activities of the settlement in the estuary valley of the Paimio River.

Acknowledgements. The author wants to thank Mr. Jukka Luoto, Phil.lic., Inst. of Archaeology, Univ. of Turku and Mr. Veli-Pekka Salonen, Phil.cand., Inst. of Geology, Univ. of Turku for help in the field work and for several discussions on the matter. She also wants to thank the Radiocarbon Dating Laboratory, Helsinki for dating the local grazing phase. analysis. 3rd rev. ed. by K. Faegri. Munksgaard, Copenhagen. 295 pp.

Fries, M., 1951. Pollenanalytisk vittnesbörd om senkvartär vegetationsutveckling, särskilt i skogshistoria, i nordvästra Götaland. Acta Phytogeog. Suec. 29, 1-220.

Glückert, G., 1976. Post-Glacial shore-level displacement of the Baltic in SW Finland. Ann. Acad. Sci Fennicae A III Geologica 118, 1-92. 
Glückert, G., 1977. Itämeren rannansiirtymisestä Turussa ja sen lähiympäristössä. Turun Yliopiston Maaperägeologian osaston julkaisuja $21,1-36$.

Havinga, A. J., 1963. A palynological investigation of soil profiles developed in cover sand. Mededel. van de Landbouehogeschool te Wageningen 63, 1-93.

Heikinheimo, O., 1915. Kaskiviljelyksen vaikutus Suomen metsiin. Reference: Der Einfluss der Brandwirtschaft auf die Wälder Finnlands. Acta Forestalia Fennica 4, 1-264, 1-149.

Iversen, J., 1964. Retrogressive vegetational succession in the post-glacial. British Ecological Society. Jubilee Symposium J. Ecol. 52 (Suppl.), 59-70.

-, 1969. Retrogressive development of a forest ecosystem demonstrated by pollen diagrams from fossil mor. Oikos Suppl. 12, 35-49.

-, 1973. The development of Denmark's nature since the last glacial. Danm. Geol. Unders. V. Raekke 7-C, 1-125.

Linkola, K., 1916. Einfluss der Kultur auf die Flora in den Gegenden nördlich vom Ladogasee. I. Allgemeiner Teil. Acta Soc. Fauna Flora Fennica 45, 1-429.

Mangerud, J., Andersen, S. T., Berglund, B. E. \& Donner, J., 1974. Quaternary stratigraphy of Norden, a proposal for terminology and classification. Boreas 3, 109-128.

National Board of Antiquities. Section for Pre- history, Helsinki, 1979. Varsinais-Suomen suojelualueet ja kohteet. Vaiheseutukaava 1 ja Salon seutukaavan muutos. Varsinais-Suomen seutukaavaliitto. $361 \mathrm{p}$.

Salo, U., 1970. Metallikautinen asutus Kokemäenjoen suussa. (Synthese: Die metallzeitliche Besiedlung an der Mündung des Flusses Kokemäenjoki). Satakunnan Museon Kannatusyhd. Pori. 219 p.

Salonen, V.-P., Ikäheimo, M. \& Luoto, J., 1981. Rautakautisen ja historiallisen asutuksen ilmeneminen paleontologisin ja arkeologisin keinoin Piikkiön Kuoppajärven ympäristössä Lounais-Suomessa. Turun Yliopiston maaperägeologian osaston julkaisuja 44, 1-23.

Siiriäinen, A., 1974. Studies relating to shore displacement and Stone Age chronology in Finland. Finskt Museum 1973, 5-22.

Suomen asutus 1560-luvulla. Kyläluettelot 1973. HY historian laitoksen julkaisuja 4, 1-259.

Tauber, H., 1967. Investigations of the mode of pollen transfer in forested areas. Rev. Palaeontol. Palynol. 3, 277-286.

Vuorela, I., 1973. Relative pollen rain around cultivated fields. Acta Bot. Fennica 102, 1-27.

,- 1980 . The vegetational and settlement history in Sysmä, Central South Finland, interpreted on the basis of two pollen diagrams. Bull. Geol. Soc. Finland 53, 47-61.

Manuscript received, January 5, 1983 